\begin{abstract}
Iranica
Abstracta Iranica Revue bibliographique pour le domaine irano-aryen

Volume 34-35-36 | 2017

Comptes rendus des publications de 2011-2013
\end{abstract}

\title{
Tobin Hartnell, Ali Asadi. Achaemenid Persepolis in context
}

\section{Astrid Nunn}

\section{(2) OpenEdition}

Journals

\section{Édition électronique}

URL : http://journals.openedition.org/abstractairanica/41574

DOI : 10.4000/abstractairanica.41574

ISSN : 1961-960X

Éditeur :

CNRS (UMR 7528 Mondes iraniens et indiens), Éditions de l'IFRI

Référence électronique

Astrid Nunn, «Tobin Hartnell, Ali Asadi. Achaemenid Persepolis in context», Abstracta Iranica [En ligne], Volume 34-35-36 | 2017, document 36, mis en ligne le 15 juillet 2016, consulté le 05 octobre 2020. URL : http://journals.openedition.org/abstractairanica/41574 ; DOI : https://doi.org/10.4000/ abstractairanica.41574

Ce document a été généré automatiquement le 5 octobre 2020.

Tous droits réservés 


\title{
Tobin Hartnell, Ali Asadi. Achaemenid Persepolis in context
}

\author{
Astrid Nunn
}

\section{RÉFÉRENCE}

Tobin Hartnell, Ali Asadi. « Achaemenid Persepolis in context », in : Roger Matthews, John Curtis, eds., Proceedings of the $7^{\text {th }}$ International Congress on the Archaeology of the Ancient Near East (ICAANE), 12 April-16 April 2010, The British Museum and UCL, London, vol. 1: Mega-cities \& Mega-sites. The Archaeology of Consumption \& Disposal; Landscape, Transport \& Communication. Wiesbaden, 2012, p. 139-155.

1 Peu d'articles de ce volume de la $7^{\text {ème }}$ ICAANE sur les mégalopoles de l'Orient Ancien abordent l'époque achéménide. Et pourtant Persépolis vient vite à l'esprit. Les AA. replacent ce site dans un contexte plus ample en y incluant la fouille de sauvetage à Tang-e Bolāgì près de Pasargades et la prospection dans la vallée du Polvār qui relie Persépolis à Pasargades. Les nouveaux résultats tendent à conforter l'hypothèse d'une habitation à faible densité pour la période achéménide autour de Persépolis. Plutôt que de considérer un système hiérarchisé d'habitation, il vaut peut-être mieux supposer des institutions spécialisées en dehors de Persépolis mais liées à l'administration centralisée dans cette cité. 


\section{AUTEURS}

\section{ASTRID NUNN}

Université de Munich 